\title{
Cooperative Law Policy: Historical Study of Cooperative Settings in Indonesia
}

\author{
Cinantya Kumaratih* and Tulus Sartono \\ Faculty of Law, Diponegoro University, Semarang-Indonesia \\ cinantya96@gmail.com
}

\begin{tabular}{|l|}
\hline \\
\hline How to cite (in APA style): \\
Kumararatih, C., \& Sartono, T. (2020). Cooperative Law Policy: Historical Study of Cooperative Settings in Indonesia. \\
Jurnal Hukum Prasada, 7(1), 34-44. https://doi.org/10.22225/jhp.7.1.1267.34-44
\end{tabular}

\begin{abstract}
The existence of cooperatives has an important meaning for the welfare state of Indonesia. As a nation that was colonized for a long time, cooperatives as one of the implementations of a people's economy became a systematic effort to correct the economic structure of a colonial style. In this study examines the legal policies of cooperative arrangements from various eras in Indonesia. This research is normative legal research with secondary data. This research shows that the existence and development of cooperatives experience ups and downs in their legal policies. The colonial period of cooperative arrangements merely regulates cooperatives in existence and makes cooperatives one of the business actors. During the independence period, the aim of cooperatives was as a people's economic movement which was expected to be able to equalize welfare. Unfortunately, cooperatives in the old and new order regimes were used as political tools to perpetuate government power. During the reform period, the regulation of cooperatives was getting worse because it made cooperatives like companies pursuing mere profits.
\end{abstract}

Keyword: Cooperative; historical study; indonesia

\section{INTRODUCTION}

The existence of cooperatives has an important meaning for the welfare state of Indonesia. As a nation that was colonized for a long time, cooperatives as one of the implementations of a people's economy became a systematic effort to correct the economic structure of a colonial style (Swasono, 2005). The economic system practiced by the capitalist colonial pattern produced a bitterness of life for the people due to the absence of humanity and justice practiced. On the other hand, the concept of cooperatives is an economic model based on the principle of kinship and the principle of cooperation which has a close relationship with the values that live in Indonesian society. A cooperative is a partnership that implements principles that guide joint efforts and the results of a common goal and aims to advance public welfare by realizing social justice for all Indonesian people. Considering the importance of the existence of cooperatives above, it is natural that cooperatives become the main pillars for the economy in Indonesia. Legally, the recognition of cooperatives is contained in the explanation of Article 33 paragraph (1) of the 1945 Constitution.

Article 33 states the basis of economic democracy, production is carried out by all, for all under the leadership or control of community members. It is the prosperity of the people that comes first not the prosperity of individuals (Chaniago, 1984). Therefore, the economy is structured as a joint effort based on the family business. Build a company that is compatible with it is a cooperative.

The explanation of the constitution is following the thoughts of Moh. Hatta over 
cooperatives as the embodiment of the principle of kinship that underlies the Indonesian economy. From Hatta's thought above, the success of cooperatives should be built on two principles, namely the principle of solidarity and the principle of individuality. The principle of social solidarity emphasizes the desire to achieve mutual prosperity. Individuality relies on self-esteem, and the ability of individuals to advance cooperatives. Individuals who are members of cooperatives must realize that they must not depend on the cooperative for their fate without doing any actions that advance the cooperative. By adhering to these two principles, cooperatives will revive the life of collective life while maintaining individuality.

Referring to the position of cooperatives above, cooperatives should be the future of the Indonesian economy in addition to State-Owned Enterprises (SOEs/BUMN), becoming a permanent economic supporter replacing business entities established from the capitalism system. But unfortunately, this has not yet been realized. Cooperatives are far behind compared to other business entities, namely SOEs and Conglomerate Companies. The above problems do not suddenly arise in cooperatives. The history of cooperatives experiences dynamics that cause cooperatives to progress at one time and backward at other times that occur unstably (Chaniago, 1984).

The dynamics of cooperative development apart from being influenced by politics are also influenced by cooperative laws. The life of a cooperative is determined by law. Cooperative laws that are formed are also bound and influenced by the conditions of political and economic ideology in their time. And in this case, the government as a legislator has an important role in determining the course of political politics. Legal politics has an extraordinary influence on the existence of cooperatives in Indonesia. Based on the background that has been described previously, the main problem in this study is about the historical study of cooperative settings policy in indonesia

\section{METHOD}

This research is legal research including normative legal research. The study was conducted using the mechanism of library research. Literature research was conducted to obtain secondary data derived from primary materials, secondary materials and tertiary materials. For this library research, the material to be used is in the form of documents. This research material in the form of books, articles, research results, and legislation, as well as related expert opinions regarding the legal politics of cooperatives in Indonesia: a historical juridical review of cooperative arrangements in Indonesia.

Normative legal research, the data associated with this legal research is analyzed descriptively qualitatively, namely by conducting an analysis which is returned to three aspects, namely classifying, comparing, and connecting. In other words, a researcher who uses qualitative methods is not merely aimed at revealing the truth, but to understand the truth. The data collected from library research will then be analyzed qualitatively to answer the proposed research problems.

\section{RESULTS AND DISCUSSION}

\section{Legal Policies on Cooperative Regulations in the Colonial Period}

The cooperative was first established in Purwokerto, Central Java in 1898 with the establishment of "hulp en spaarbank" by R. Aria Wiriaatmadja, a regent in Purwokerto whose purpose was to safeguard the interests of civil servants, so that they were free of debts to usurers. Although not entirely as a cooperative bank, the presence of the institution has moved the hearts of Assistant De Wolf van Westerrode to encourage the construction of credit cooperatives for farmers throughout the Banyumas residency (Harsoyo, 2006). De Wolf Van Westerrode then created an agricultural credit organization according to the type of Bank Raiffeisen of Germany. Lending is no longer limited to civil servants but is extended to farmers who fall prey to usurers and bonded labor who must be cured of social ills (Tambunan, 2008).

Cooperatives are increasingly developing at the same time as the national movement. Budi Utomo, which was founded in 1908, advocated the establishment of cooperatives for household use, while Sarekat Islam developed cooperatives engaged in 
daily necessities. Before the birth of Budi Utomo, there were no ideals for establishing cooperatives by the people. The existing cooperative was established by Dutch employees and its existence depends on the Dutch Indian government (Swasono, 2005). The cooperative that was established at that time had a national spirit towards improving the people's lot. The establishment of cooperatives was facilitated by the Dutch colonial government to undermine Indonesia's growing young capitalism. Colonial capitalism did not provide a developing opportunity for young Indonesian capitalism, thus opening the way of life for its opponents, namely Indonesian cooperatives. Unfortunately, with the rapid development of cooperatives making the colonial government worried because the cooperative movement also brought political and social enthusiasm in it. Therefore the government is trying to prevent the growth and development of cooperatives through legislation. The first cooperative arrangement was verordening op de cooperative verenigingen (Statsblad 431 of 1915). This regulation regulates cooperatives in general both established by Dutch people and by indigenous people. In the regulation, there are several provisions which are very burdensome for the growth and development of cooperatives. The first difficulty is the notarial deed of establishment. The second difficulty is because the bureaucracy is not easy to deal with in registration (Swasono, 2005). To establish a cooperative must go to court it must first obtain permission from the GovernorGeneral of the Dutch East Indies government. The third difficulty is the obligation to announce in newspapers in Malay and Dutch. The fourth difficulty is in the financing because the material costs incurred are very large, the costs have not been added to the notary public and the costs of making newspaper announcements. To take care of the establishment and so on the Cooperative must at least issue 170 Gulden for financing. 50 Gulden is equivalent to nine quintals of rice (Chaniago, 1984).

Furthermore, in cooperative management arrangements, strong interventions from the government were also found. The regulation is found in Article 11 and Article 12. The regulation in Article 11 states the obligation to provide an official register book from the government. The book contains detailed data of each member, management and employee which includes the name, first name or other name and place of residence as well as the work of the board and supervisor; Furthermore, Article 12 regulates the entry of a person to become a member of an association which must be verified by member parties and third parties by signature and must be notarized. In the above regulation, the government carries out strict supervision for members, management and supervisors of cooperatives, particularly the regulation of Article 11 which is specifically for indigenous people. This can be seen from the government's efforts to find out their background with the rules to mention their first names. Even the management and supervisors must also provide information about their residence and work to the government (Melianti, 2002). Also, in the organization of membership in cooperatives, the government closes access to society to become members. Cooperatives in these arrangements have lost their principles regarding the principle of member openness and independence. Cooperatives become elitist organizations for certain circles (Nurhayati \& Wibowo, 2011).

The regulation has received widespread resistance in society especially from the movement. In response to the refusal in 1920 a "Cooperative Commission" was chaired by $\mathrm{J} . \mathrm{H}$ Boeke. The commission is tasked to examine the extent to which the needs of the population of the son of the earth to cooperate. The results of this commission report that cooperatives in Indonesia indeed need to be developed and given ease in their establishment. Based on that in 1927 the Inlandsce Cooperative Vereningen Statsblad 91 was established in 1927 (Regulation on Bumiputera Cooperative Groups 1927 State Gazette Number 91. In these Regulations for the establishment of cooperatives was facilitated. Easy arrangements include Article 3, Article 5, Article 7 paragraph (1) up to paragraph (5) and Article 11.

According to the provisions of Article 3, cooperatives established by Bumiputera use the law that applies to Bumiputera. One of the permits under Bumiputera law is that cooperatives receive land rights, that is, they can buy and/or pawn land and rice fields. This right is more suitable and more beneficial for Indonesian cooperatives, especially agricultural cooperatives. Article 5 of the Cooperative Regulation of 1927 concerning 
governing deeds of the establishment of cooperatives is simpler and easier than the previous arrangement. In this article, the choice is given in the use of the language used to make the deed, namely regional languages, Malay languages or Dutch languages. In addition to the use of language, the process of submitting a deed of the establishment of the government to obtain legal status is also made easier. In the process of filing a deed for the establishment of a cooperative to obtain a legal entity in the regulation becomes simpler. The deed of establishment no longer uses the deed from a notary, it does not require permission from the Governor-General. The deed is sufficient to be submitted to an advisor for the cooperative people's credit affairs. Besides the establishment of cooperatives also need not be announced in the newspaper. The most important convenience is that all processes in registration, submission, and announcement are free of charge. This will certainly be very helpful for cooperatives. To set up cooperatives to be cost-effective (Tambunan, 2008).

Another arrangement that provides the last facility that can be found in the regulation of cooperative membership openness principles. The entry and exit of members are sufficiently evidenced by the recording in the list. Thus, there is no need for a third party, nor do officials or notaries make official letters as members. Community access to participate in building cooperatives is becoming more open and easier. Other facilities were provided as a follow up to the regulation Cooperatie Dienst (Cooperative Service) in 1930 under the Department van Binnenlandshe Bestuur (Ministry of Home Affairs) and in 1932 issued Government Decree Number 29 contained in Staatsablad Number 634 of 1932, which established that cooperatives established under Staatsblad Year 1927 Number 91 have been tax free for 10 years since they were founded. With the special arrangement of the child's earth, Indonesia applies the concept of dualism in law. This concept was proposed by J.H Boeke who examined the reasons for the failure of Dutch colonial (economic) policy in Indonesia from the standpoint of economic sociology (Sitio, 2001). The concept was developed based on the reality of two different social systems between native and non-native. If differences are not accommodated, there will be a clash in the community. Therefore, by arrangement, if the two cannot be united then two different rules must be given for each. This dualism of cooperative arrangement continued when Verordening op De Cooperative Verenigingen Statsblad 431 of 1915 was replaced by Algemeene Regeling op de Cooperative Vereeniiging Staatsblad 103 of 1933. The replacement was adjusted to the new Dutch Cooperative Law, which was formed in 1925 (Nurhayati \& Wibowo, 2011).

During the Japanese occupation, the conditions of cooperative arrangements did not change much. Japan does not make new rules in cooperatives. Japan only stipulates that all Government Agencies and legal and statutory powers from the previous Government remain to be recognized temporarily, provided that they do not conflict with Military Government Regulations (Marpaung, 2014). Although Japan recognized the 1927 Regulation, Japan also issued a regulation that had an impact on the existence of cooperatives, namely regulation No. 23 of 1942 which governs associations and trials. In Article 2 the regulation stipulates that to establish an association (including cooperatives), as well as to hold hearings or meetings of the association, the founders or their management must obtain prior permission from the Resident. Permission is granted on condition that the association or trial concerned is in no way a political movement.

If it is observed that this regulation intends to supervise associations, including cooperatives in terms of the police. This arrangement ultimately limits and even kills the space for cooperatives in Indonesia. That is because cooperatives are one of the most important things that the movement organization fought for at the time. With the Japanese regulation, many cooperatives stopped their businesses because they did not get a permit. This coincided with the banning of movement organizations during the Japanese occupation.

\section{The Political Law of Post-Independence Cooperative Arrangements}

Cooperatives have gained a special place since the founding of Indonesia. This is indicated in the Indonesian constitution, especially Article 33 paragraph (1) which states: 
"The economy is organized as a joint effort based on the principle of kinship". On the principle of kinship. Build a company that is compatible with it is a cooperative. The question is, why are cooperatives chosen? There are two answers to respond to that question. First, cooperatives are considered concepts that can fight oppression by capitalism. Second, cooperatives are the most suitable and most appropriate concept for creating people's welfare.

For these two answers, for example, it can be found in the thoughts of Sukarno and Hatta as the proclamation and leader of Indonesia at that time. In his thoughts Sukarno once wrote: "we are moving because we are not willing to set capitalism and imperialism, and the first condition for aborting capitalism and imperialism must be independence. We must be independent so that we can freely hook the rope to abort the system of capitalismimperialism. We must be them so that we can freely establish a new society without capitalism, imperialism" (Tambunan, 2008).

In the article, Soekarno stated that the purpose of the struggle was not merely to obtain independence, more than that independence was only a means to fight capitalism and imperialism. Why? Because Indonesia has felt the pain caused by colonialism with the character of capitalism and imperialism. The Indonesian people cannot enjoy the natural wealth generated from their earth.

Economic democracy in the explanation of the 1945 Constitution by Sukarno in his writings was described as a concept of democracy that provides welfare to its people. The economy operates from, by, and for the people. Soekarno explicitly wanted to say that capitalism and imperialism would be lost if the economy was not ruled by a handful of people but by all the people. The right container and following the principle recommended by Sukarno was a cooperative (Marpaung, 2014).

The existence of cooperatives is not only as a micro-economy which is one of the business entities but also as a macro-economy. The path of the Indonesian economy should be based on cooperative policies (Nurhayati \& Wibowo, 2011). The state's obligation is not merely to acknowledge cooperatives by allowing them to compete with the giants of capitalism, but the state should give priority to cooperatives for good growth and development. But on the other hand, the state is also not allowed to intervene because it will eliminate the identity of the cooperative itself.

\section{Regulations on Cooperatives in the Old Order}

The statutory regulations that initially governed cooperatives were Cooperative Societies 1949 State Institutions 1949 No. 179. Judging from the material contained in the Act, it was no different from the Regulations of Inlandsce Cooperative Vereningen Statsblad 91 of 1927. Hal as stated in Article 1 which reads: "Regulations on Indonesian Cooperative Societies (Bumiputera) as referred to in the March 19, 1927, ordinance, are reestablished as follows: Regulations on Cooperative Societies in 1949". As was the 1927 cooperative regulations, In the 1949 regulation, the role of the government was only to facilitate the administration. The government only regulates how cooperatives are established and how they are endorsed (Swasono, 2005). The state acts passively towards the growth and development of cooperatives in Indonesia. Such an arrangement was certainly not following the wishes of the nation's leaders at the time who expected cooperatives to have more contribution in developing the people's economy. The government must make efforts so that the cooperative develop well without removing the character of the cooperative itself. As a result of the mismatch of these arrangements finally in 1958, Law No. 79 of 1958 concerning Cooperative Societies was made. The regulation is a cooperative law that was first made by the Indonesian people themselves. In-Law Number 79 of 1958 concerning cooperative associations, the government has an active role in promoting cooperatives. There are several important points in the arrangement (Swasono, 2005). First, the regulation of cooperative characters that are more active include: 1). requiring and activating its members to save regularly; 2 ). educate members towards cooperative awareness; and 3) organize one or several business fields in the field of cooperatives (Harsoyo, 2006).

Secondly, there is an active role of the government in promoting cooperatives 
which hold guidelines to guide the people to live cooperatively towards the implementation of the law and provide assistance and concessions to the cooperative movement (Abdullah, 2014). Guidance on the cooperative movement lies with the government intending to ensure the operation of Indonesian people's businesses to control the economy through the cooperative. The cooperatives also receive government assistance including legal protection, education, subsidies and facilities to run their businesses. One manifestation of this assistance is the ease of establishing cooperatives.

Beyond positive arrangements above, there are some arrangements which are seen as too much government intervention. Some of these arrangements include restrictions on the type and level of cooperatives in each cooperative work area and the existence of too far involvement in coaching and supervising cooperatives by the state (Masngudi, 1990). Although there is no absolute limit on the amount of work in each area, it means that similar cooperatives or similar cooperatives can be established, but this regulation will have a difficult effect on proposing the establishment of cooperatives to the government. In terms of mentoring, the involvement of the government to have the right to speak and even be allowed to hold member meetings and executive meetings will eliminate the independence of the cooperative itself (Sitio, 2001).

The good spirit in promoting cooperatives as they should have not lasted long. One year after the formation of the quo Law, an implementing regulation was formed in the form of Government Regulation Number 60 of 1959 concerning the Development of the Cooperative Movement. This rule distorts the laws on cooperative collections. This is evident in the main points of thought contained in the consideration of the Government Regulation which essentially places cooperatives in state intervention. Cooperatives must adjust to government policies and the government must take an active attitude in fostering cooperative movements based on the principles of guided democracy (Marpaung, 2014).

Some provisions of Government Regulation No. 60 of 1959 concerning the development of the Cooperative Movement are considered to have denied the spirit to promote cooperatives. First, the provisions regarding cooperative management are developed uniformly for all types of cooperatives. May be members of cooperatives in each type of cooperative are people who have the same interests or have direct interests in the type of cooperative. For example in farmer cooperatives, only farmers and those who are allowed to become members of cooperatives. Besides that, in villages, first-level regions, second-level regions and at the central level, the cooperative structure has been uniformed. Second, if there is more than one type of cooperative in one working area, in the shortest possible time it will be united (merged) by the government. Third, cooperatives are spoiled by the state by eliminating or avoiding as far as possible from the competition with private businesses. The existence of these regulations caused the cooperative to become limited in space and lose the initiative to develop its business. In addition to these arrangements, cooperatives during the guided democracy period were not cooperatives that were born and developed from the community. Cooperatives are institutions that are set up top-down, meaning that most of the establishment is carried out by the state. This is reflected in the general explanation that the government is still scheduled for the formation of cooperatives by the government in business fields that control the lives of many people.

Cooperatives as an extension of the government are not only in their structure and establishment. In MPRS Tap Number II / MPRS / 1960 concerning the Outline of the First Stage of National Development Planning in 1961-1969 and Government Regulation Number 140 of 1961 concerning Distribution of Goods and Materials for Basic Needs of the People, the Cooperative stands for hands of the country. The cooperatives chosen by the state to become a liaison institution with the people. The cooperative is given business by the state as a distributor of staples for the people. Even in the TAP MPRS a quo the role of cooperatives has more priority than national private companies. This is valid as long as it does not kill the creativity of the cooperative, but the facts on the field of the cooperative become dependent on the government (Masngudi, 1990).

Government intervention on cooperatives does not stop there. As the peak of the politicization of cooperatives in the old order, in 1965 Law No. 14 of 1965 concerning Cooperatives was made. This law clearly and firmly places cooperatives under state 
intervention. Cooperatives are economic organizations and tools of the Revolution that function as a nursery for people and vehicles for Indonesian Socialism based on Pancasila. Article 5 also emphasizes Cooperatives, the structure, activities of the coaching tools and equipment of cooperative organizations, reflecting the progressive national cooperation of the NASAKOM revolutionary (Suryani, 2015)

\section{Regulations on Cooperatives in the New Order}

The new order is the antithesis of the old order. The direction of state policy adopted by these two regimes is contradictory to one another. If during the old order Indonesia followed socialism in economic development, during the new order liberalism was a guide in economics. This is marked by the inclusion of Law No. 1 of 1967 concerning Foreign Investment (PMA). With the existence of this Law, the domination of foreign capital over national capital is inevitable and defeats the work done by Indonesians, especially cooperatives (Suryani, 2015).

At the same time as the birth of the Foreign Investment Law, almost all policies taken by the old order, in the new order were annulled (Marpaung, 2014). Including those annulled by the new order are cooperative arrangements. With the establishment of the new order regime, cooperative arrangements have also changed. Law Number 14 of 1965 Cooperatives are revoked and replaced with Law Number 12 of 1967 concerning Cooperative Principles. The reason for the revocation is because Law No. 14 of 1965 concerning Cooperatives contains thoughts that want to place cooperatives as political servants, this is indicated because of government intervention that has gone too far. In connection with this matter in the explanation of this law which states: "The role of the Government that is too far in regulating the problems of Indonesian cooperatives as has been reflected in the past is essentially non-protective, even very limiting the movement and implementation of basic economic strategies that are not following the soul and meaning of Article 33 of the 1945 Constitution. it will hinder the steps and limit the characteristics of self-reliance, self-reliance, and participation which are the main elements of the principles of trust in oneself, which in turn will be detrimental to the community itself".

The old order policies that pulled cooperatives into the vortex of political conflict were broken by the new order. Cooperatives are returned to their functions as stated in the Act, the functions of cooperatives are 1). economic struggle tools to enhance people's welfare; 2 ). tools for democratizing the national economy; 3 ). as one of the arteries of the Indonesian economy; and 4). the tools of community development to strengthen the economic position of the Indonesian nation and be united in regulating the management of the people's economy.

With the quo law, it is as if the intervention of the government is over, and the cooperative becomes an independent people's economic movement. Unfortunately, some arrangements contradict this spirit. This is stated in the regulation of cooperative type, especially Article 15 and Article 17. In Article 15 regulates: 1). following needs and for efficiency purposes, cooperatives can focus on higher-level coordination; 2). The lowest level cooperatives up to the top level in centralizing relations as referred to in paragraph (1) of this Article constitute an inseparable unit; 3). Higher-level cooperatives are obliged and authorized to carry out guidance and inspections of lower-level cooperatives, and 4). Relationships between levels of similar cooperatives are regulated in the Articles of Association of each similar Cooperative. Whereas Article 17 regulates: 1). The type of cooperative is based on the needs of oneself and for the efficiency of a group in a homogenous society because of the similarity of economic activities/interests to achieve the common goals of its members; and 2). For efficiency and order, in the interests and development of the Indonesian Cooperative, in each working area, there are only similar and equivalent cooperatives.

In the above arrangements, government intervention is very strong even though the government does not directly interfere in the daily management of cooperatives. The design of cooperatives regulated in the above regulation in Article 15 is top-down, there are superior cooperatives and subordinate cooperatives. Centralization occurred in cooperative institutions. Primary cooperatives focus on central cooperatives, central cooperatives under 
joint cooperatives and joint cooperatives under the parent cooperative. Relationships that occur are not from the bottom as elements that form superiors' cooperatives that are authorized to inspect and supervise, the opposite of cooperatives at the top level who guide and inspect cooperatives underneath (Budiyono \& S, 2015). In the centralized cooperative arrangement, the government through the Parent cooperatives can intervene to all cooperatives under it.

The above is increasingly emphasized by the regulation of Article 17 which regulates the organization of cooperatives. Cooperatives are classified based on the homogeneity of the community based on the common activities / economic interests of their members. This means that a cooperative is established and consists of people who have the same profession (Sitio, 2001). So it is not surprising if based on the Law a quo, civil servant cooperatives, and $A B R I$ cooperatives are raised. Cooperatives under the state institutions will be easily intervened and commanded by the government because they must comply with all existing policies.

In the development of the new order regime, Law Number 12 of 1967 concerning Cooperative Fundamentals in 1992 was changed to Law Number 25 of 1992 concerning Cooperatives. In terms of legal ideas, this Law continues the Laws that were previously formed. In Cooperative Law, the definition of Cooperative undergoes a fundamental paradigm change. Cooperatives are given the meaning of cooperatives as a business entity consisting of individuals or legal entities of cooperatives by basing their activities based on cooperative principles as well as a people's economic movement based on the principle of kinship. in this definition the cooperative has highlighted its form as a business entity, meaning that the cooperative has been released to conduct economic business. The cooperative has been allowed to seek business profits. This is different from the previous definition that defines cooperatives as associations or as economic organizations (Suryani, 2015).

In-Law Number 25 Year 1992 concerning Cooperatives, Regulations that further restrict and limit the space for cooperatives are those concerning Cooperative Movement Institutions. In Article 57 concerning this institution, the Cooperative regulated together to establish a single organization that functions as a forum to fight for interests and act as carriers of Cooperative aspirations. In this arrangement, all cooperatives will later be joined in one single organization. If there is a cooperative that does not agree with organizational policies, the cooperative cannot do anything because the organization is the only legitimate cooperative forum. As a single forum, the organization is vulnerable to being politicized from its internal management. This organization has the following tasks: 1). Fighting and channeling Cooperative aspirations; 2). Increase awareness of cooperatives in the community; 3). Conducting cooperative education for members and communities; and 4). Develop cooperation between cooperatives and members of cooperatives with other business entities, both at national and international levels.

Task point (1) above derogates the existence of cooperatives as autonomous organizations. After the founding of the organization, the voice of each cooperative to channel their aspirations was taken by the organization. Cooperatives no longer have the right to fight for and channel their aspirations. In this new order period, cooperatives became an extension of the government. Its existence is engineered in such a way that it abandons the basic principles of cooperatives.

\section{Cooperative Arrangements in the Reformation Period}

More than a decade after the reform, new cooperative arrangements were replaced. It is Law Number 17 of 2012 concerning Cooperatives which replaces Law Number 25 of 1992. Unfortunately, this Law is far from the fire to advance cooperatives. What exists weakens cooperatives and contradicts the Basic Law. This law has only been carried out for two years and was then canceled by the Constitutional Court in its entirety. The Cooperative Law has been deemed to have lost its spirit because it is no longer based on cooperative principles. Cooperatives are designed as capitalist companies that are solely looking for profit, not aimed at the welfare of its members. Even cooperatives by definition become land for profit-seeking by individuals. In this examination, the Court granted the 
petition and canceled the entire Law number 17 of 2012 with several considerations (Sulaiman, Irwansyah, \& Maryono, 2014).

First, it relates to the definition of cooperatives set out in Article 1 number 1 of Law Number 17 of 2012 concerning "Cooperatives are legal entities established by individuals or Cooperative legal entities, with the separation of the wealth of their members as capital to run a business, which fulfills common aspirations and needs in the economic, social and cultural fields in accordance with Cooperative values and principles". The Court responded that the formulation of cooperatives is (as) a legal entity that does not contain a substantive understanding of cooperatives as referred to in Article 33 paragraph (1) of the 1945 Constitution and its Explanations which refer to the understanding as building a typical company. According to the Court, the cooperative is about who the cooperative is, or in other words, the formulation that prioritizes cooperatives in the perspective of the subject or as economic actors, which is part of the economic system. For this purpose, it is formulated with words or phrases, associations, economic organizations, or people's economic organizations. Or, at least in a cooperative formulated as a "business entity". So that the formulation of cooperatives in Law Number 17 of 2012 which does not indicate an economic agent, is contrary to the Constitution because it contains individualism (Rochmadi, 2011).

Second, regarding the appointment of non-member management. The existence of these regulations hinders or even negate the rights of cooperative members to express opinions, vote, and be elected as well as the values of kinship, responsibility, democracy, and equality that form the basis of cooperatives. Cooperative is an organization that is built and developed based on the association of people, the goal is the welfare of individuals. If the person who is going to decide on management is outside the members, then it is a deviation from the fundamental principles of the cooperative (Sulaiman \& Maryono, 2014). Cooperatives are expected to grow better along with the capacity of members of the cooperative who are qualified in managing cooperatives (Susilo, 2013). To make cooperatives a professional organization, the members of the cooperative must be built to become professionals. To realize this, certainly, the principle of education and training for members of the cooperative plays an important role.

Third, about cooperative capital. In the regulation of the quo Law regulating cooperative capital is the Principal Deposit and Cooperative Capital Certificate as initial capital, besides it can also come from grants, investment capital, loan capital from members, etc. Concerning the provisions which state that the Principal payment is paid by the Member at the time the application is filed as a Member and cannot be returned, it cannot be justified. The principal deposit in a cooperative must be seen as a form of a person's decision to join voluntarily as a member of the cooperative, so if the member decides to leave or quit for some reason, naturally, the principal savings are withdrawn. About capital certificates that require members to buy, this is not following the principles of volunteerism and openness. This means, the orientation of the cooperative has shifted towards a pool of capital, which has thus denied the identity of the cooperative as a gathering of people with joint ventures as its main capital. With this arrangement, it is feared that the cooperative will lose its uniqueness in making important decisions. Meanwhile, capital certificate arrangements which when released cannot be sold outside but must be purchased by other members or by cooperatives. This is the same as the principal deposit arrangement. there is an element of coercion in it. What if fellow members do not want to buy, or cooperative money is not enough. This is detrimental to members of the Cooperative (Sulaiman et al., 2014).

The last thing related to cooperative capital is an investment. This must be avoided because it opens the intervention of outside parties, including the government and foreign parties, through unlimited capital. Cooperatives as a group of people are thus no different from a limited liability company as a collection of capital, or even as a publicly listed public limited company that raises capital as much as possible with no limit to the risk of opening opportunities for intervention from parties outside the cooperative (Swasono, 2005).

Fourth, the Prohibition of Distribution of Surplus Business Results Derived from Transactions with Non-Members. There is an injustice related to rights and 
obligations, that is, when a cooperative experiences a surplus of the results of operations the member is not entitled to but when the cooperative experiences a deficit of operating results, whether caused by transactions with members or non-members, members are required to deposit the cooperative's capital certificate as additional capital. In this arrangement, the cooperative seems to place itself as an entity separate from its members. In fact, what is owned by cooperatives should be used for the welfare of its members, because that is the purpose of cooperatives.

Fifth, about the types of cooperatives. In this arrangement, the cooperative is forced to choose one of the types specified in this law. This arrangement does not match the facts in the field relating to the development of cooperatives. limiting the types of cooperative business activities has contained the creativity of cooperatives to determine their types of business activities, which may be, along with the development of science, technology, culture, and economy, also developing types of business activities to meet human economic needs. This arrangement has wanted to dwarf the existence of cooperatives (Rachman, 2016). If a corporation (PT) is permitted to form a conglomerate, why does the Cooperative have to be limited in their business fields? This makes the injustice of cooperatives actors and movers. Many multi-purpose cooperatives have succeeded.

With all of the above considerations, it would be appropriate if the Constitutional Court annulled the entire Cooperative Law. Arrangements relating to fundamental principles are contrary to the identity of the cooperative itself. The Constitutional Court has saved the political direction of legal regulation of cooperatives in Indonesia.

\section{CONCLUSION}

One thing that becomes homework together concerning the decision of the Constitutional Court is the dictum of the ruling which states that Law Number 25 of 1992 concerning Cooperatives is valid temporarily until the formation of the new Law. As discussed in the above research, Law Number 25 of 1992 itself has violated many cooperative principles and is no longer relevant for enforcement. Even in the stipulations in Law Number 25 of 1992 in some cases regulating the same content as the Act that was canceled. for example, in the capital, Law Number 25 of 1992 also recognizes capital investment. Besides that, in the SHU distribution, members are also only given a profitsharing proportional to the business services performed by each member. What if the transaction is done with non-members? The Court should also provide an interpretation of some of the provisions in Law Number 25 of 1992. Of course, this decision also raises constitutional problems, especially the Constitutional Court does not set a time limit on how long the new cooperative law must be made.

\section{REFERENCES}

Abdullah, S. (2014). Politik Hukum Penanaman Modal Asing Setelah Berlakunya Undang-Undang Penanaman Modal 2007 Dan Implikasinya Terhadap Pengusaha Kecil. Fiat Justisia, 8(4), 546 -570. Retrieved from https://doi.org/10.25041/fiatjustisia.v8no4.320

Budiyono, T., \& Indah S, C. M. (2015). Pergeseran Politik Hukum Koperasi dalam UU RI No. 25 Tahun 1992 dan UU No. 17 Tahun 2012 Serta Putusan Mahkamah Konstitusi No. 28/PUU RIXI/2013. Masalah-Masalah Hukum. 44(3), 336-347. Retrieved from http://dx.doi.org/10.14710/ mmh.44.3.2015.336-347

Chaniago, A. (1984). Perkoperasian Indonesia. Bandung: Agkasa.

Harsoyo, Y. (2006). Ideologi Koperasi Menatap Masa Depan. Jakarta: Pustaka Widyatama.

Marpaung, M. (2014). Pengaruh Kepemimpinan dan Team Work terhadap Kinerja Karyawan di Koperasi Sekjen Kemdikbud Senayan Jakarta. Jurnal IImiah WIDYA, 2(1), 33-40. Retrieved from

Isi_Artikel_393539707348.pdf http://digilib.mercubuana.ac.id/manager/t!@file_artikel_abstrak/

Masngudi, H. (1990). Penelitian tentang sejarah perkembangan koperasi di Indonesia. Jakarta: Badan Penelitian Perkembangan Koperasi.

Melianti, Y. (2002). Dukungan Koperasi Dalam Pengembangan UKM Menurut Perspektif Politik Hukum Ekonomi. Jurnal Pengabdian Kepada Masyarakat. 8(28), 45-53. Retrieved from http:// digilib.unimed.ac.id/id/eprint/66 
Nurhayati, S., \& Wibowo, E. (2011). Peningkatan sumber daya manusia menuju ekonomi rakyat berbasis koperasi indonesia, 245-250.

Rachman, I. N. (2016). Politik Hukum Pengelolaan Sumber Daya Alam Menurut Pasal 33 UUD 1945 Jurnal Konstitusi. 13(1), 191-212. Retrieved from https://media.neliti.com/media/ publications/112850-ID-politik-hukum-pengelolaan-sumber-daya-al.pdf

Rochmadi, I. (2011). Analisis Dampak Perdagangan Bebas dan Global pada Bergesernya Nilai Budaya, Prinsip dan Tujuan Koperasi. Jurnal Ekonomika, 4(2), 45-51. Retrieved from http:// www.kopertis7.go.id/uploadjurnal/Ekonomika_201112_Vol04_No02_2.pdf

Sitio, A. (2001). Koperasi: Teori dan Praktek. Jakarta: Erlangga.

Sulaiman, H. I., Irwansyah., \& Maryono. (2014). Implementasi Corporate Social Responsibility (CSR) pada Hasnur Group (Study pada anak perusahan Hasnur Group Wilayah Kalimantan Selatan dan Kalimantan Tengah). Jurnal Bisnis Dan Pembangunan, 1(1), 8-15. Retrieved from https:// ppjp.ulm.ac.id/journal/index.php/bisnispembangunan/article/download/797/694.

Suryani, P. (2015). Perkembangan Gabungan Koperasi Batik Indonesia (GKBI) di Yogyakarta 19481980 (Doctoral dissertation, Universitas Gadjah Mada). Retrieved from http:// etd.repository.ugm.ac.id/home/detail_pencarian/92947

Susilo, E. (2013). Peran Koperasi Agribisnis dalam Ketahanan Pangan di Indonesia. Jurnal Dinamika Ekonomi Dan Bisnis, 10(1), 95-104. Retrieved from https://ejournal.unisnu.ac.id/ JDEB/article/download/28/39

Swasono, S. E. (2005). Koperasiz Nilai Tambah Ekonomi, Nilai Tambah Sosio Kultural Sokoguru Perekonomian. Jakarta: Yayasan Hatta.

Tambunan, T. (2008). Prospek Perkembangan Koperasi di Indonesia ke depan: Masih Relevankah Koperasi di dalam Era Modernisasi Ekonomi. Pusat Studi Industri dan UKM Universitas Trisakti. Retrieved from http://www.kadin-indonesia.or.id/enm/images/dokumen/KADIN-982927-16062008.pdf

Undang-Undang Dasar Negara Republik Indonesia 1945.

Undang-Undang Nomor 79 Tahun 1958 tentang Perkoperasian.

Undang-Undang Nomor 14 Tahun 1965 tentang Perkoperasian.

Undang-Undang Nomor 12 Tahun 1967 tentang Pokok-Pokok Perkoperasian.

Undang-Undang Nomor 25 Tahun 1992 tentang Perkoperasian.

Undang-Undang Nomor 17 Tahun 2012 tentang Perkoperasian. 